ANALISIS NILAI TAMBAH TEBU DI PABRIK GULA KWALA MADU PTPN II

\title{
ANALYSIS OF ADDITIONAL VALUE AT PABRIK GULA KWALA MADU PTPN II
}

\author{
Muhammad Thamrin ${ }^{1}$ Desi Novita ${ }^{2}$ dan Dita Ananda Sari ${ }^{1}$ \\ ${ }^{1}$ Program Studi Agribisnis Fakultas Pertanian UMSU-Medan \\ ${ }^{2}$ Program Studi Agribisnis Fakultas Pertanian UISU-Medan \\ email : mhdthamrin@umsu.ac.id
}

\begin{abstract}
This research was conducted at Pabrik Gula Kwala Madu PT. Perkebunan Nusantara II in Desa Kwala Begumit, Kecamatan Stabat, Kabupaten Langkat. The purpose of this research is to know the development of production and productivity of cane and sugar, to know the added value from cane processing to sugar. The research method used is survey method, with the sample of this research is staff processing section and staff section of production, sample determination is done by purposive sampling. The first used analysis method is trend analysis to know the development of cane and sugar production, the second using hayami method for value-added analysis. The results of this study show that the development of caneand sugar production and productivity at Pabrik Gula Kwala Madu PTPN II from 2007-2017 always fluctuated. The increase and decrease of production is not fixed every year. The result of value added analysis of sugarcane by using hayami method showed that the added value of cane to sugar obtained is positive because the value added ratio > $0 \%$ is equal to $75 \%$.
\end{abstract}

Keywords: Cane, Sugar, Added Value, Production, Productivity

\section{ABSTRAK}

Penelitian ini dilakukan di Pabrik Gula Kwala Madu PT. Perkebunan Nusantara II di Desa Kwala Begumit, Kecamatan Stabat, Kabupaten Langkat. Tujuan penelitan ini adalah untuk mengetahui perkembangan produksi serta produktivitas tebu dan gula, untuk mengetahui nilai tambah dari hasil pengolahan tebu menjadi gula. Metode penelitian yang digunakan adalah metode survei, dengan sampel penelitian ini adalah staff dibagian pengolahan dan staff dibagian produksi, penentuan sampel dilakukan dengan purposive sampling. Metode analisis yang digunakan yang pertama adalah analisis trend untuk mengetahui perkembangan produksi tebu dan gula, yang kedua menggunakan metode hayami untuk analisis nilai tambah. Hasil penelitian ini menunjukan bahwa perkembangan produksi serta produktivitas tebu dan gula di Pabrik Gula Kwala Madu dari tahun 2007-2017 selalu mengalami fluktuasi. Peninggkatan dan penurunan produksi tidak tetap setiap tahunnya. Hasil penelitian analisis nilai tambah tebu dengan menggunakan metode hayami menunjukkan nilai tambah tebu menjadi gula yang didapat adalah positif karena rasio nilai tambah $>0 \%$ yaitu sebesar $75 \%$.

Kata Kunci: Tebu, Gula, Nilai Tambah, Produksi, Produktivitas

\section{A. PENDAHULUAN}

Pembangunan perekonomian Indonesia berkaitan erat dengan pembangunan pertanian, mengingat Indonesia merupakan negara agraris yang sebagian besar masyarakatnya adalah petani. Pembangunan pertanian dengan pendekatan agroindustri merupakan alternatif pilihan yang dapat dikembangkan, sejalan dengan perkembangan ekonomi dan perdagangan diera globalisasi yang menuntut adanya efisiensi dan efektivitas usaha. Produk pertanian dan agroindustri semakin diharapkan dalam pembangunan nasional.

Tebu merupakan tanaman perkebunan musiman yang mengandung zat gula pada batang nya yang digunakan sebagai bahan baku produksi gula dalam negeri. Tebu hasil panen dapat dijual ke pabrik gula untuk memenuhi permintaan pasar akan gula. Produksi tebu nasional tahun ke tahun menunjukan adanya fluktuasi.

Badan Ketahanan Pangan Nasional mengatakan sistem produksi, produktivitas dan efisiensi pada pangan strategis seperti gula masih cukup lemah. Sistem produksi gula sebenarnya tidak dapat dipisahkan dari karakter sistem usahatani tebu skala kecil dan berafiliasi dengan PT. Perkebunan Nusantara dengan persoalan efisiensi teknik dan efisiensi ekonomi. Kinerja industri gula nasional pada dekade terakhir mengalami penurunan baik dari sisi areal, produksi maupun tingkat efisiensi.

Produktivitas tanaman tebu dipengaruhi oleh berbagai faktor yaitu penggunaan sarana produksi dan teknik budidayanya. Pelaksanaan pemupukan yang efisien yaitu waktu pemberian dan cara pemberian. Kombinasi jenis dan jumlah pupuk yang digunakan berkaitan erat 


\section{Muhammad Thamrin, Desi Novita, Dita Ananda Sari}

dengan tingkat produktivitas dan rendemen tebu ${ }^{1}$.

Rendemen tebu merupakan kandungan gula yang terdapat pada tebu. Untuk mendapatkan rendemen yang tinggi, tanaman harus bermutu baik dan ditebang pada saat yang tepat. Berbagai kasus yang mencuat dan bahkan menyebabkan konflik antara petani dan pabrik gula adalah karena ketidakjelasan penentuan rendemen ${ }^{2}$.

Produksi adalah segala kegiatan dalam menciptakan dan menambah kegunaan (utility) sesuatu barang dan jasa, untuk kegiatan mana dibutuhkan faktor-faktor produksi dalam ilmu ekonomi berupa tanah, tenaga kerja, dan skill (organization, managerial, dan skills) ${ }^{3}$.

Produktivitas menyatakan rasio antara output dan input. Dalam pekerjaan pengukuran produktivitas, terlebih dahulu harus disusun defenisi kerja dan kemudian cara mengukur baik output maupun input. Secara garis besar setiap variabel dapat dinyatakan dalam satuan fisik atau satuan nilai rupiah. Produktivitas dipengaruhi oleh suatu kombinasi dari banyak faktor, antara lain: varietas, tingkat kesesuaian lahan (termasuk luas dan kualitasnya), jenis teknologi yang digunakan, ketersediaan modal, kualitas pupuk dan input lainnya, ketersediaan dan kualitas infrastruktur pendukung (seperti irigasi) dan tingkat pendidikan/pengetahuan petani ${ }^{4}$.

Di Sumatera Utara program ini dilaksanakan sejak tahun 2006. Penurunan produktivitas antara lain disebabkan faktor baku teknik budidaya yang tidak pernah dicapai. Menurunnya produktivitas lebih banyak disebabkan oleh aktivitas budidaya tebu telah menyimpang dari baku teknik budidaya mulai dari jarangnya menggunakan bibit dari sumber bibit sehat dan berkualitas, pengolahan tanah yang kurang sempurna, pemeliharaan tanaman seadanya, serta kurang baiknya penanganan tebang, muat dan angkut ${ }^{5}$.

Pada proses distribusi komoditas pertanian terjadi arus yang mengalir dari hulu kehilir, yang berawal dari petani dan berakhir pada konsumen akhir. Komoditas pertanian mendapat perlakuan-perlakuan seperti pengolahan, pengawetan, dan pemindahan untuk menambah kegunaan atau menimbulkan nilai tambah. Ada dua cara untuk menghitung nilai tambah yaitu dengan cara menghitung nilai tambah selama proses pengolahan dan menghitung nilai tambah selama proses pemasaran ${ }^{6}$.

Peningkatan nilai tambah dari suatu produk agribisnis pada dasarnya tidak terlepas dari aplikasi teknologi yang tepat dan sistem manajemen yang professional. Besarnya nilai tambah tergantung dari teknologi yang digunakan dalam proses produksi dan adanya perlakuan lebih lanjut terhadap produk yang dihasilkan. Suatu perusahaan dengan teknologi yang lebih baik akan meningkatkan produk dengan kualitas yang lebih baik pula, sehingga harga produk olahan akan lebih tinggi dan akhirnya akan memperbesar nilai tambah yang diperolehnya ${ }^{7}$.

Industri pengolahan hasil pertanian dapat menciptakan nilai tambah. Jadi konsep nilai tambah adalah suatu pengembangan nilai yang terjadi karena adanya input fungsional seperti perlakuan dan jasa yang menyebabkan bertambahnya kegunaan dan nilai komoditas selama mengikuti arus komoditas pertanian ${ }^{8}$. Selanjutnya perlakuan-perlakuan serta jasa-jasa yang dapat menambah kegunaan komoditi tersebut disebut dengan input fungsional. Input fungsional dapat berupa proses mengubah bentuk (from utility), menyimpan (time utility), maupun melalui proses pemindahan tempat dan kepemilikan.

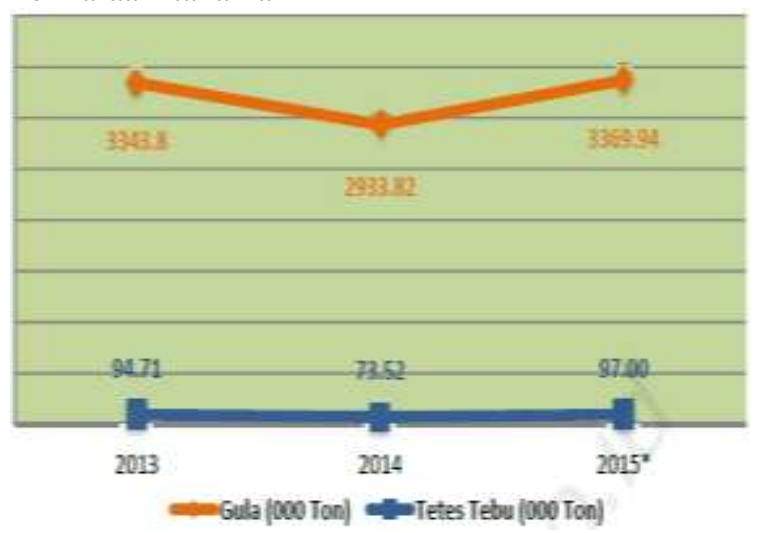

Gambar 1. Grafik perkembangan volume impor gula dan tetes tebu Indonesia, 2013-2015*

Gambar 1 Menunjukan grafik perkembangan volume impor gula di Indonesia mengalami fluktuasi dimana pada tahun 2014 mengalami penurunan sebesar 409,98 ton dari tahun 2013 dan kembali naik pada tahun 2015 sebesar 436,12 ton. Sedangkan tetes tebu juga 
ANALYSIS OF ADDITIONAL VALUE AT PABRIK GULA

mengalami fluktuasi volume impor pada tahun 2014 menurun sebesar 21.19 ton dan mengalami

penaikan pada tahun 2015 sebesar 23,48 ton.

Tabel 1. Luas Panen, Produksi dan Produktivitas Tanaman Tebu Perkebunan Besar Negara Tahun 20132015 Provinsi Sumatera Utara

\begin{tabular}{ccll}
\hline Tahun & $\begin{array}{c}\text { Luas Panen } \\
(\mathrm{Ha})\end{array}$ & Produksi (Ton) & $\begin{array}{c}\text { Produktivitas } \\
(\text { Ton/Ha })\end{array}$ \\
\hline 2013 & 7.198 & 29.485 & 4.096 \\
2014 & 6.975 & 26.571 & 3.809 \\
2015 & 6.298 & 24.071 & 3.822 \\
\hline
\end{tabular}

Sumber:Direktorat Jendral Perkebunan

Tabel 1 merupakan hasil produksi tebu perkebunan negara di Sumatera Utara dari tahun 2013-2015 produksi tebu setiap tahun mengalami penurunan. Maka produksi gula juga menurun. Hal ini dikarenakan pabrik gula yang ada di Indonesia cenderung menurun karena produksi bahan baku tebu yang tiap tahun mengalami penurunan produksi. Luas panen juga setiap tahun mengalami penurunan karena terjadinya konversi lahan mulai dari penggarapan lahan perkebunan oleh masyarakat sekitar dan pengalihan tanaman dari tebu menjadi tanaman perkebunan lain.

Di Sumatera Utara memiliki dua pabrik gula yaitu Pabrik Gula Kwala Madu dan Pabrik Gula Sei Semayang. Namun yang masih beroperasi adalah Pabrik Gula Kwala Madu sedangkan Pabrik Gula Sei Semayang mulai dari tahun 2014 sudah tidak beroperasi karena Pabrik Gula Sei Semayang kekurangan bahan baku tebu untuk diproses menjadi gula. Pabrik Gula Kwala Madu merupakan salah satu pabrik gula yang masih mengolah tebu menjadi gula.

Dengan demikian, peneliti ingin melakukan penelitian di Pabrik Gula Kwala Madu guna untuk melihat bagaimana perkembangan produksi tebu dan gula dan nilai tambah yang dihasilkan dari proses pengolahan yang dilakukan di daerah penelitian.

Perumusan Masalah

1. Bagaimana perkembangan produksi dan produktivitas tebu dan gula di PTPN II Kwala Madu?

2. Berapa nilai tambah yang diperoleh dari pengolahan tebu sehingga menjadi gula?

\section{B. METODE PENELITIAN}

Metode survei adalah metode yang digunakan untuk mendapatkan data dari tempat tertentu yang alamiah (bukan buatan) ${ }^{8}$.
Penelitian dilakukan di Pabrik Gula Kwala Madu PT. Perkebunan Nusantara II di Desa Kwala Begumit, Kecamatan Stabat, Kabupaten Langkat. Pemilihan lokasi dilakukan secara sengaja (purposive).

Metode pengambilan sampel dalam penelitian ini dilakukan secara Purposive Sampling dimana teknik pengambilan sampel sumber data dengan pertimbangan tertentu. Pertimbangan tertentu yang dimaksud seperti orang yang ahli dibidangnya ${ }^{9}$. Dengan metode tersebut, maka ditetapkan yang menjadi sampel penelitian ini adalah staff ahli bidang pengolahan dan staff ahli dibagian produksi di Pabrik Gula Kwala Madu. Data yang dikumpulkan dalam penelitian ini terdiri dari data primer dan data sekunder. Periode pengumpulan data dimulai dari tahun 20072017.

Metode analisis data untuk mengidentifikasi rumusan masalah pertama menggunakan Analisis trend. Analisis trend digunakan untuk mengetahui perubahan nilai variabel dari waktu ke waktu juga dimaksudkan untuk melihat kecenderungan tingkat pertumbuhan produksi serta produktivitas gula dan tebu di PTPN II Kwala Madu. Maka digunakan rumus sebagai berikut :

$$
\begin{aligned}
& \% \text { pertumbuhan produksi }=\frac{Y_{t-Y}}{Y_{t}} \times 100 \% \\
& \text { Keterangan: } \\
& \text { Yt }=\text { Hasil produksi } \\
& \mathrm{Yt}_{-1}=\text { Hasil produksi sebelum Yt } \\
& \text { Untuk mengidentifikasi rumusan masalah } \\
& \text { kedua mengenai nilai tambah yang diperoleh } \\
& \text { dari hasil pengolahan tebu sehingga menjadi } \\
& \text { gula, maka dianalisis dengan menggunakan } \\
& \text { metode hayami. Analisis nilai tambah dengan } \\
& \text { menggunakan metode hayami adalah sebagai }
\end{aligned}
$$
berikut:

Tabel 2. Perhitungan Nilai Tambah Dengan Menggunakan Metode Hayami

\begin{tabular}{llc}
\hline No & Output, Input, Harga & Formula \\
\hline 1 & Hasil produksi (kg/tahun) & $\mathrm{A}$ \\
2 & Bahan baku (kg/tahun) & $\mathrm{B}$
\end{tabular}




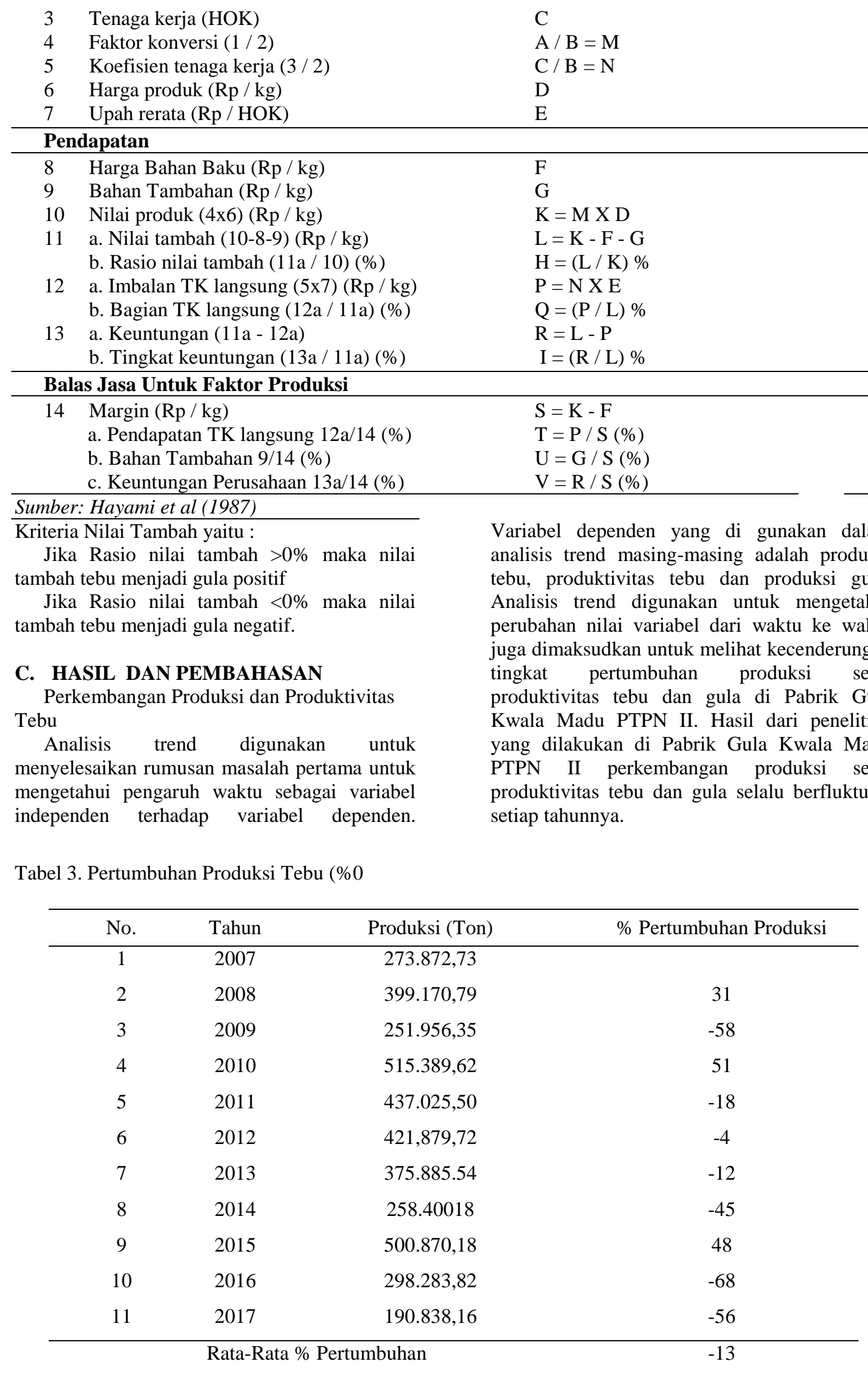

Sumber: Data Sekunder Diolah, 2018. 
Pada Tabel 3 persen pertumbuhan produksi tebu di Pabrik Gula Kwala Madu PT. Perkebunan Nusantara II mengalami fluktuasi jumlah produksi tebu setiap tahunnya. Rata-rata persen pertumbuhan tahun selama 10 tahun adalah sebesar -13\%. Persen pertumbuhan produksi tebu tertinggi berada pada tahun 2010 yaitu sebesar 51\%. Sedangkan persen pertumbuhan produksi tebu terendah berada ditahun 2016 dengan nilai sebesar $-68 \%$.

\section{PRODUKSI TEBU}

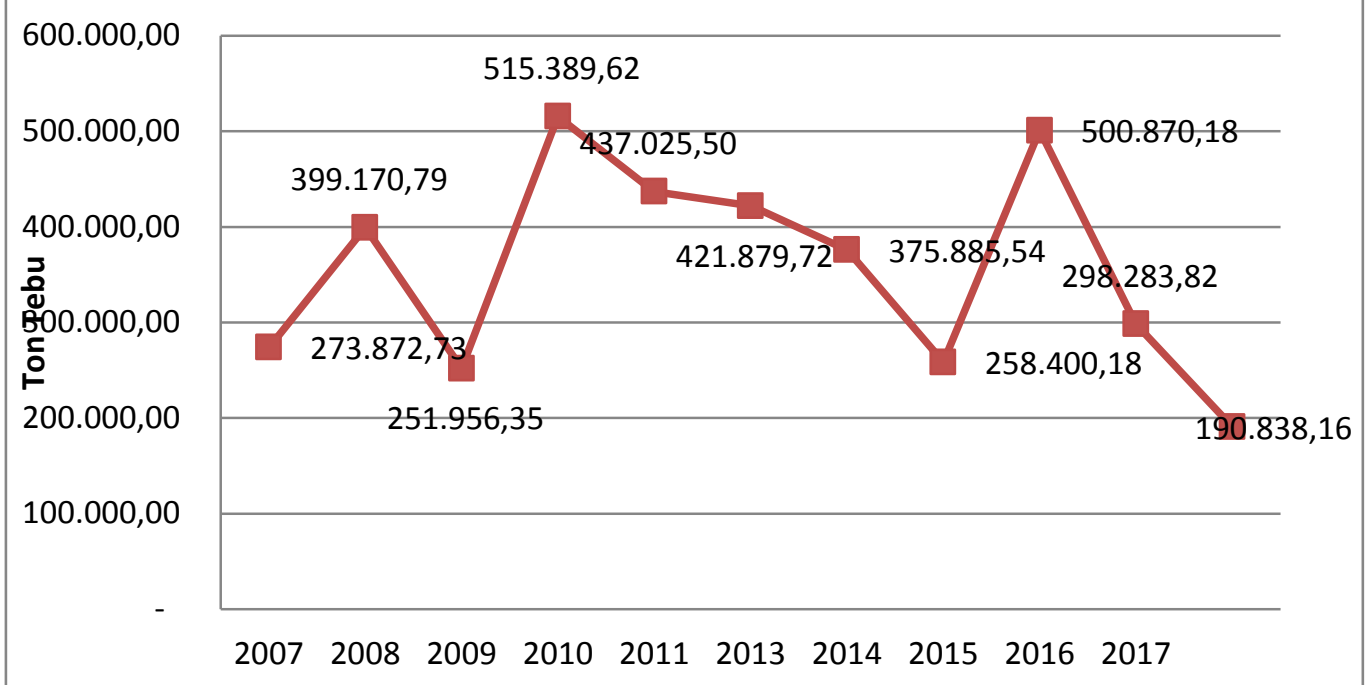

Gambar 2. Grafik Perkembangan Produksi Tebu Tahun 2007-2017

Dari tabel persen produksi dan grafik produksi tebu dapat dilihat bahwa selama kurun waktu 11 tahun produksi tebu selalu terjadi penurunan dan peningkatan produksi tebu yang tidak tetap pada tiap tahun yang berbeda. Ratarata persen pertumbuhan produksi tebu adalah 13\%. Pada tahun 2010 terjadi peningkatan produksi tebu hingga $51 \%$ dengan angka produksi 515.389,62 ton tebu. Dan pada tahun 2016 merupakan jumlah persen produksi tebu dari tabel yang paling rendah sebesar $-68 \%$, sedangkan dari grafik pada tahun 2017 penurunan produksi tebu terendah dengan jumlah produksi tebu sebesar 190.838,16 ton tebu. Naik turunnya produksi setiap tahun banyak faktor yang mempengaruhi seperti pengalihan fungsi lahan perkebunan tebu yang dialihkan ketanaman perkebunan lainnya, penggarapan lahan perkebunan tebu oleh masyarakat dan kurang maksimalnya perawatan pada saat proses penanaman.

Tabel 4. Pertumbuhan Produktivitas Tebu (\%)

\begin{tabular}{cccc}
\hline No. & Tahun & Produktivitas (Ton/Ha) \\
\hline 1 & 2007 & 50.39 & 6 \\
2 & 2008 & 53.78 & -18 \\
3 & 2009 & 45.64 & 26 \\
4 & 2010 & 61.64 & 22 \\
5 & 2011 & 79.48 & -30 \\
6 & 2012 & 61.13 & -4 \\
7 & 2013 & 58.82 & -8 \\
8 & 2014 & 54.52 & 16 \\
9 & 2015 & 64.56 & -34 \\
10 & 2016 & 48.22 & -14 \\
11 & 2017 & 42.33 & \\
\hline
\end{tabular}




\begin{tabular}{ll}
\hline & Rata-Rata \% Pertumbuhan \\
\hline Sumber: Data Sekunder Diolah, 2018. & \\
Dari Tabel 4 persen pertumbuhan & menjadi persen produktivitas tebu tertinggi \\
produktvitas tebu rata-rata selama 10 tahun & yaitu sebesar 26\%, dan persen produktivitas \\
terakhir adalah $-4 \%$. Dimana pada tahun 2010 & terendah pada tahun 2016 dengan angka $-34 \%$.
\end{tabular}

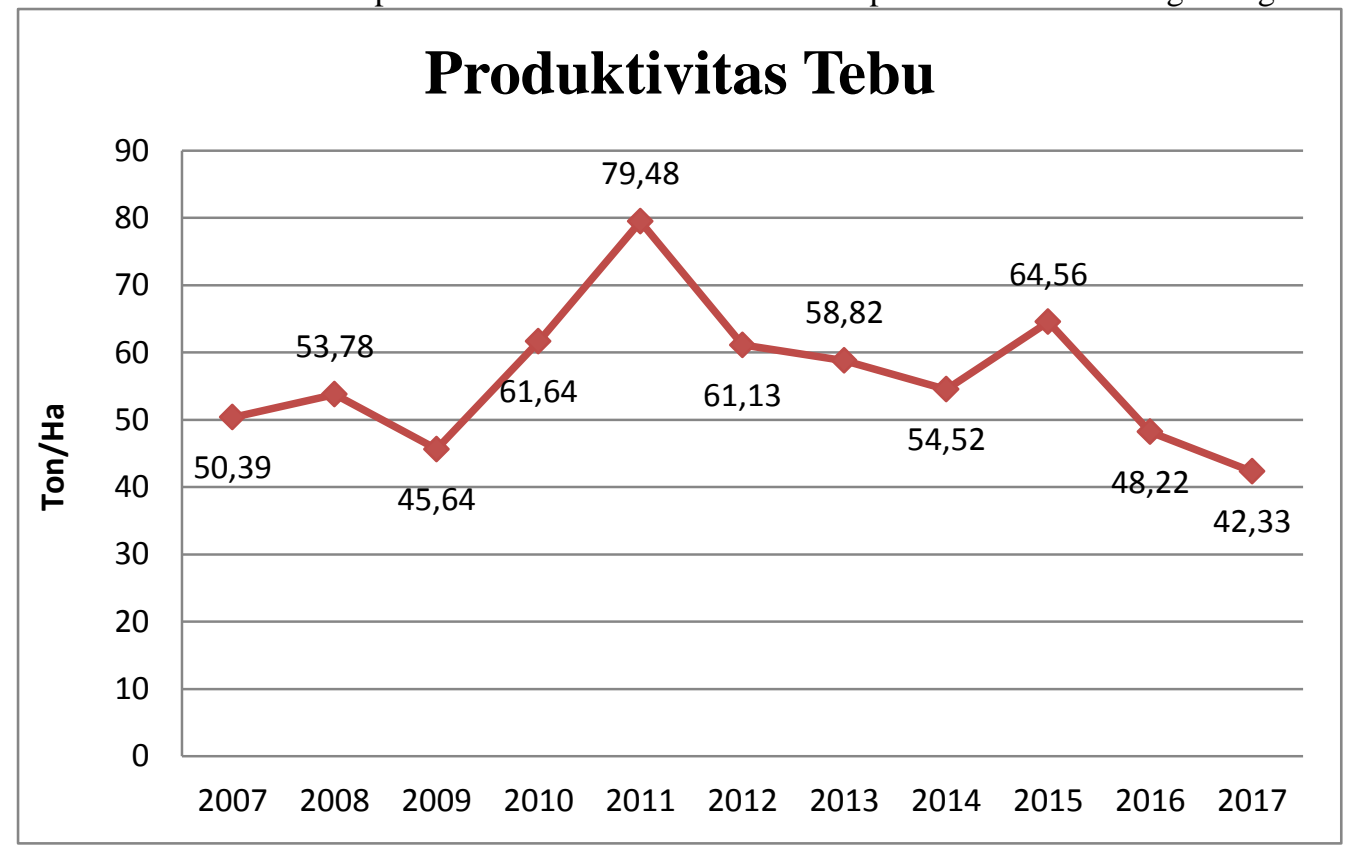

Gambar 3. Grafik Perkembangan Produktivitas Tebu Tahun 2007-2017

Dilihat dari Tabel dan Grafik produktivitas tebu pada tahun 2007-2017 rata-rata persen pertumbuhan produtivitas sebesar $4 \%$, dan pada tahun 2010 persen pertumbuhan produktivitas menjadi yang paling tinggi selama 10 tahun terakhir sebesar $26 \%$ dengan jumlah produktivitas 61,64 ton/ha. Dan produktivitas tertinggi ditahun 2011 sebesar 79,48 ton/ha. Pada tahun 2016 adalah tahun pada saat persen produktivitas tebu terendah sebesar $-38 \%$. Dan produktivitas terendah pada tahun 2017 sebesar 42,33 ton/ha. Naik dan turunnya produktivitas tebu juga dipengaruhi oleh luas lahan tebu yang setiap tahun terjadi pengurangan dan penambahan yang berbeda. Faktornya masih dari penggarapan lahan oleh masyarakat atau alih fungsi lahan perkebunan tebu di alih fungsikan untuk tanaman lain yang dirasa lebih menguntungkan. Luas lahan sangat berpengaruh terhadap jumlah produksi tebu yang akan dihasilkan, karena apabila lahan sedikit maka jumlah produksi tebu pun menjadi berkurang, begitu pun sebaliknya apabila luas lahan semakin banyak maka jumlah produksi tebu pun akan meningkat namun jika di imbangi juga dengan perawatan tanaman tebu secara maksimal, maka produksi tebu akan meningkat dan tebu yang dihasilkan berkualitas.

Perkembangan Produksi Gula

Produksi gula dari PT. Perkebunan Nusantara II Kwala Madu hasil setiap tahunnya berfluktuasi sama seperti produksi dan produktivitas tebu. Karena jumlah tebu yang diproduksi juga berpengaruh terhadap besarnya hasil gula yang diproduksi di Pabrik Gula Kwala Madu PTPN II.

Tabel 5. Pertumbuhan Produksi Gula (\%)

\begin{tabular}{cccc}
\hline No. & Tahun & Produksi (Ton) & $\%$ Pertumbuhan Produksi Gula \\
\hline 1 & 2007 & $17.077,00$ & \\
2 & 2008 & $22.619,00$ & 25 \\
3 & 2009 & $14.347,49$ & -58 \\
4 & 2010 & $30.785,00$ & 53 \\
5 & 2011 & $24.806,50$ & -24
\end{tabular}




\begin{tabular}{cccc}
6 & 2012 & $24.997,00$ & 1 \\
7 & 2013 & $24.836,50$ & -1 \\
8 & 2014 & $18.259,75$ & -36 \\
9 & 2015 & $29.657,00$ & 38 \\
10 & 2016 & $17.877,50$ & -66 \\
11 & 2017 & $9.504,00$ & -88 \\
\hline
\end{tabular}

Sumber: Data Sekunder Diolah, 2018.

Dari Tabel 5 persen pertumbuhan produksi gula juga mengalami fluktuasi tiap tahunnya, sama seperti persen pertumbuhan produksi tebu. Dilihat dari Tabel 5 nilai rata-rata persen pertumbuhan produksi gula adalah $-16 \%$. Persen pertumbuhan tertinggi selama 10 tahun berada pada tahun 2010 yaitu 53\%. Sedangkan persen pertumbuhan produksi terendah yaitu pada tahun 2017 sebesar $-88 \%$.

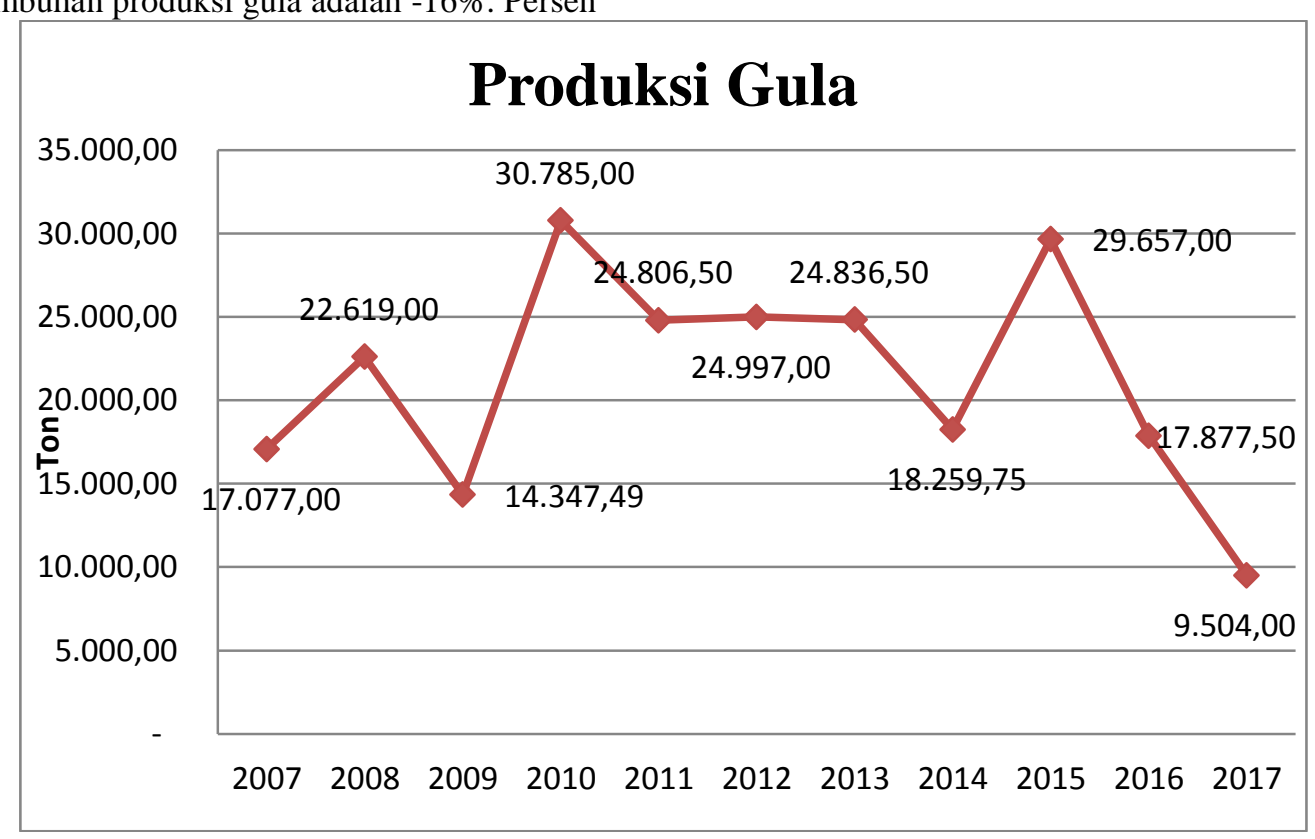

Gambar 4. Grafik Perkembangan Produksi Gula Tahun 2007-2017

Dari Gambar 4 merupakan grafik perkembangan produksi gula yang diolah di Pabrik Gula Kwala Madu PT. Perkebunan Nusantara II dari tahun 2007-2017. Jumlah produksi gula sama dengan produksi tebu berfluktuasi setiap tahunnya. Rata-rata persen pertumbuhan produksi gula sebesar $-16 \%$. Jumlah produksi tertinggi pada tahun 2010 sebesar 30.785,00 ton. Sedangkan persen pertumbuhan produksi gula tertinggi adalah $53 \%$ pada tahun 2010. Jumlah produksi gula paling menurun pada tahun 2017 sebesar 9.540,00 ton gula, persen pertumbuhan produksi gula paling rendah juga pada tahun 2017 yaitu sebesar $-88 \%$.

Naik turunnya produksi gula tidak hanya karena banyaknya jumlah produksi tebu yang dihasilkan, tetapi kadar rendemen gula yang terdapat dalam tebu juga sangat mempengaruhi berapa besar jumlah gula yang dihasilkan dari proses pengolahan. Apabila produksi tebu tinggi namun rendemen gula dalam tebu rendah maka hasil produksi gula akan menurun, namun apabila produksi tebu tidak tinggi tetapi kadar rendemen gula dalam tebu tinggi maka hasil produksi gula bisa meningkat. Rendemen gula sangat berperan penting dalam jumlah produksi gula, rendemen yang tinggi biasa dipengaruhi dari umur tanaman tebu dan faktor cuaca. Rendemen yang baik pada saat tebu berumur 11-12 bulan untuk tanaman pertama, dan untuk tanaman kedua, ketiga dan keempat biasanya 11 bulan siap panen dan rendemen yang cukup tinggi. Selain umur panen tebu, rendemen bisa menurun apabila perawatan tebu tidak maksimal. Dan faktor cuaca juga mempengaruhi tingkat rendemen yang terdapat dalam tebu, apabila sebelum masa panen tebu musim hujan, maka rendemen tebu akan menurun dan jumlah produksi gula pun akan menurun. Itulah penyebab naik turunnya produksi gula. 


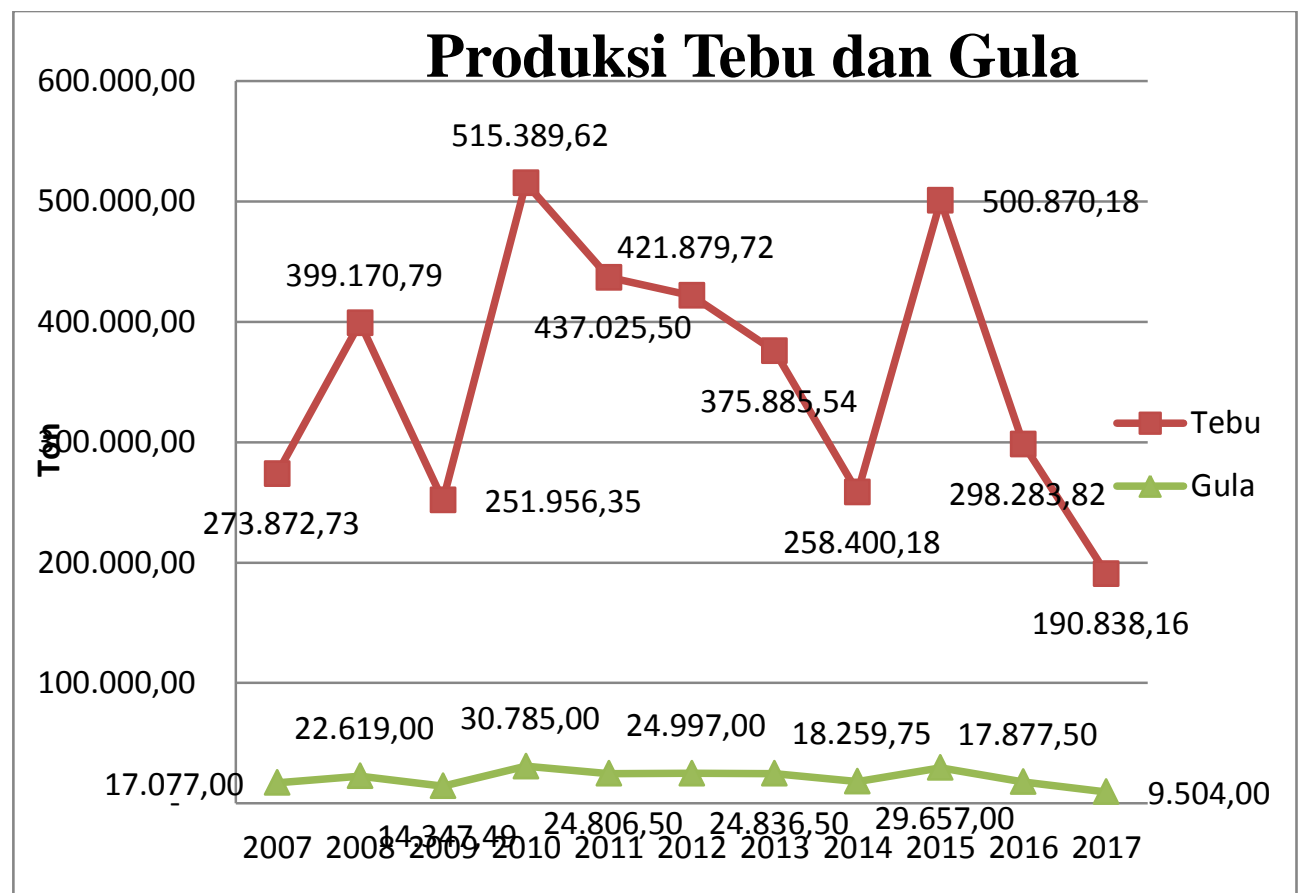

Gambar 5. Grafik Produksi Tebu dan Gula Tahun 2007-2017

Dari gambar 5 grafik produksi tebu dan gula penurunan dan peningkatan produksi tiap tahunnya tidak tetap. Produksi tebu tertinggi ditahun 2010 dengan jumlah produksi gula yang tertinggi juga ditahun yang sama. Jumlah tebu sebesar 515.389,62 ton dan jumlah gula yang dihasilkan sebesar $30.785,00$ ton. Sedangkan jumlah produksi tebu terendah dan jumlah produksi gula terendah berada ditahun 2017. Jumlah produksi tebu sebesar 190.838,16 ton dan jumlah produksi gula yang dihasilkan sebesar 9.504,00 ton. Dapat disimpulkan bahwa jumlah produksi tebu berpengaruh terhadap jumlah produksi gula yang dihasilkan dari proses pengolahaan dipabrik. Namun selain jumlah produksi tebu, kadar rendemen gula yang terdapat didalam tebu juga sangat mempengaruhi jumlah produksi gula yang dihasilkan.

Nilai Tambah

Perhitungan nilai tambah yang diperoleh dari proses pengolahan suatu produk dapat menggunakan Metode Hayami. Kelebihan dari analisis nilai tambah dengan menggunakan Metode Hayami adalah pertama, dapat diketahui besarnya nilai tambah, nilai output, dan produktivitas, kedua, dapat diketahui besarnya balas jasa terhadap pemilik-pemilik faktor produksi, serta ketiga, prinsip nilai tambah menurut Hayami dapat diterapkan untuk subsistem lain diluar pengolahan, misalnya untuk kegiatan pemasaran ${ }^{10}$.

Melihat besarnya nilai tambah digunakan metode Hayami. Menurut Hayami, nilai tambah adalah selisih antara komoditas yang mendapat perlakuan pada tahap tertentu dengan nilai yang di gunakan selama proses berlangsung. Kegiatan pengolahan tebu menjadi gula akan mengakibatkan bertambahnya nilai komoditas tersebut $^{11}$.

Metode analisis yang digunakan untuk mengetahui nilai tambah yang diperoleh dari pengolahan tebu sehingga menjadi gula adalah Metode Hayami. Perhitungan nilai tambah yang dilakukan pada proses pengolahan tebu di pabrik gula dengan tujuan untuk mengukur besarnya nilai tambah yang terjadi akibat adanya proses pengolahan tebu menjadi gula yang siap dipasarkan. Analisis nilai tambah berguna untuk menguraikan masing-masing faktor-faktor produksi menurut sumbangan masing-masing faktor-faktor produksi, serta berguna untuk mengetahui distribusi nilai tambah terhadap tenaga kerja. Berikut ini merupakan tabel perhitungan nilai tambah dengan menggunakan Metode Hayami adalah sebagai berikut : 


\section{ANALYSIS OF ADDITIONAL VALUE AT PABRIK GULA}

Tabel 6. Hasil Perhitungan Nilai Tambah dengan Menggunakan Metode Hayami

\begin{tabular}{clr}
\hline No & Output, Input, Harga & Gula \\
\hline 1 & Hasil Produksi (Kg /Tahun) & 9.504 .000 \\
2 & Bahan Baku (Kg/Tahun) & 190.838 .160 \\
3 & Tenaga Kerja (HOK) & 132.600 \\
4 & Faktor Konversi (1 / 2) & 0,05 \\
5 & Koefisien Tenaga Kerja (3 / 2) & 0,0007 \\
6 & Harga Produk (Rp / Kg) & 9.090 \\
7 & Upah Rerata (Rp / HOK) & 101.858 \\
\hline & Pendapatan & 0 \\
\hline 8 & Harga Bahan Baku (Rp / Kg) & 114,32 \\
9 & Bahan Tambahan (Rp / Kg) & 452,69 \\
10 & Nilai Produk (4x6) (Rp / Kg) & 338,37 \\
11 & A. Nilai Tambah (10-8-9) & 75 \\
& B. Rasio Nilai Tambah (11a / 10) (\%) & 70,77 \\
12 & A. Imbalan TK Langsung (5x7) (Rp/Kg) & 21 \\
& B. Bagian TK Langsung (12a / 11a) (\%) & 267,60 \\
13 & A. Keuntungan (11a - 12a) & 79 \\
\hline & B. Tingkat Keuntungan (13a / 11a) (\%) & 452,69 \\
\hline & Balas Jasa Untuk Faktor Produksi & 16 \\
14 & Margin (Rp / Kg) & 25 \\
& A. Pendapatan TK Langsung 12a/14 (\%) & 59 \\
\hline & B. Bahan Tambahan 9/14 (\%) & \\
& C. Keuntungan Perusahaan 13a/14 (\%)
\end{tabular}

Sumber:Data Sekunder Diolah, 2018.

Berdasarkan penelitian yang dilakukan maka produk yang dihasilkan dari Pabrik Gula Kwala Madu adalah berupa gula. Gula merupakan salah satu bahan sembako yang dibutuhkan oleh masyarakat dalam memenuhi kebutuhan hidup sehari-hari. Penjelasan mengenai perhitungan yang terdapat pada Tabel 6, dapat dilihat sebagai berikut :

Dari Tabel 6, dilihat bahwa hasil produksi berupa gula yang dihasilkan adalah sebesar $9.504,000 \mathrm{~kg} /$ tahun. Hasil produksi ini diperoleh selama 98 hari VII periode giling pada tahun 2017 dimana pada periode I selama 15 hari, periode II selama13 hari, periode III selama 15 hari, periode IV selama 16 hari, periode V selama 15 hari, periode ke VI selama 15 hari dan periode ke VII selama 9 hari. Sedangkan bahan baku yang digunakan dalam proses pengolahan ini adalah tebu. Tebu yang akan digiling merupakan tebu yang telah masak panen dan sesuai dengan kriteria yang telah ditentukan. Bahan baku awal harus ada setiap kali akan melakukan kegiatan produksi karena bahan baku merupakan kunci utama dalam proses pengolahan yang akan berlangsung.

Dari Tabel 6, tebu yang diperoleh sebanyak $190,838,160 \mathrm{~kg} / \mathrm{tahun}$. Tebu-tebu tersebut diperoleh dari Unit Kebun Kwala Madu, Kebun
Sei Semayang, dan Tebu dari petani TRI. Karena tebu yang dihasilkan oleh kebun Kwala Madu tidak mencukupi kapasitas giling dan Pabrik Gula Sei Semayang juga sudah tidak beroperasi lagi, maka Pabrik Gula Kwala Madu juga memperoleh tebu yang berasal dari Kebun Sei Semayang dan petani TRI.

Namun walaupun begitu jumlah bahan baku masih tidak bisa menghasilkan jumlah gula yang banyak karena, jumlah produksi gula tidak hanya dipengaruhi oleh banyak nya jumlah produksi tebu tetapi dipengaruhi oleh tingkat rendemen gula yang terdapat pada tebu.

Dari Tabel 6, faktor konversi yang diperoleh adalah sebesar 0,05. Faktor konversi ini diperoleh dari pembandingan antara hasil produksi dengan bahan baku. Nilai konversi ini menunjukkan bahwa setiap pengolahan $1 \mathrm{~kg}$ tebu akan menghasilkan $0,05 \mathrm{~kg}$ gula. Sedangkan koefisien tenaga kerja merupakan pembandingan antara tenaga kerja dengan bahan baku, maka nilai yang diperoleh dari koefisien tenaga kerja adalah sebesar 0,0007.

Dalam melaksanakan kegiatan produksinya Pabrik Gula Kwala Madu membutuhkan tenaga kerja. Adapun tenaga kerja langsung yang berpengaruh terhadap proses pengolahan di Pabrik Gula Kwala Madu sebanyak 442 orang. 
Bekerja 8 jam 1 hari dan selama 300 hari dalam setahun, maka tenaga kerja yang dibutuhkan adalah sebesar 132,600 HOK.

Pendapatan dari Tabel 6, dapat dilihat bahwa Pabrik Gula Kwala Madu tidak membeli bahan bahan baku. Hal ini dikarenakan adanya bagi hasil antara pihak kebun Kwala madu dengan Kebun Sei Semayang dan Petani TRI. Sehingga pada metode hayami, harga bahan baku bernilai nol (0) rupiah. Sistem pembagian hasilnya untuk gula yang dihasilkan $35 \%$ untuk pabrik Kwala Madu dan 65\% untuk Kebun Sei Semayang atau Petani TRI. Dalam proses pengolahan tebu menjadi gula dibutuhkan bahan tambahan pengolahan yang dimasukkan dalam memproduksi gula sehingga menghasilkan gula yang sesuai dengan kriteria/standart yang telah ditentukan. Bahan tambahan yang dimaksud merupakan bahan tambahan yang ditambahkan secara langsung ke dalam proses pengolahan sebagai komposisi produk yang bertujuan untuk menyempurnakan produk akhir yang dihasilkan. Biaya bahan tambahan dengan metode hayami sebesar Rp. 114,32/ Kg, nilai ini diperoleh dari perbandingan total biaya bahan tambahan yang diperlukan untuk proses pengolahan gula dengan jumlah gula yang dihasilkan. Lampiran 4 menujukkan rincian biaya bahan tambahan pengolahan tebu menjadi gula.

Nilai produk gula yang dihasilkan sebesar Rp. 452,69 / kg, nilai produk ini diperoleh dari perkalian antara faktor konversi dan harga produk. Nilai tambah yang diperoleh dari pengolahan tebu menjadi gula adalah sebesar Rp. $338,37 / \mathrm{kg}$. Nilai tambah yang diperoleh dari pengurangan nilai produk dengan harga bahan baku dan nilai input lain. Rasio nilai tambah gula yang diperoleh sebesar $75 \%$, hal ini berarti rasio nilai tambah tebu menjadi gula $>0 \%$ berarti memberikan nilai tambah positif. Rasio nilai tambah diperoleh dari perbandingan hasil nilai tambah dengan nilai produk dikali dengan $100 \%$.

Imbalan tenaga kerja langsung diperoleh dari perkalian antara koefisien tenaga kerja dengan upah rerata tenaga kerja yaitu sebesar Rp. $70,77 / \mathrm{Kg}$, sedangkan persentasi imbalan tenaga kerja langsung terhadap nilai tambah gula adalah $21 \%$. Imbalan terhadap modal dan keuntungan diperoleh dari nilai tambah dikurangi dengan besarnya imbalan tenaga kerja. Keuntungan dari pengolahan tebu menjadi gula adalah Rp. 267,60/Kg. Dan tingkat keuntungan gula didapat dari perbandingan keuntungan dengan nilai tambah yaitu sebesar $79 \%$. Tingkat keuntungan untuk menunjukkan berapa besar persentase keuntungan terhadap nilai tambah tebu menjadi gula.

Balas Jasa Untuk Faktor Produksi
Hasil analisis nilai tambah dengan Metode Hayami ini juga dapat menunjukkan marjin dari bahan baku tebu menjadi gula yang didistribusikan kepada imbalan tenaga kerja, sumbangan input lain, dan keuntungan perusahaan. Margin ini merupakan selisih antara nilai produk dengan harga bahan baku. Nilai

Margin gula yang diperoleh adalah sebesar Rp. 452,69/kg. Bagian pendapatan tenaga kerja dari pengolahan diperoleh dari perbandingan antara imbalan tenaga kerja dengan margin dikali dengan $100 \%$. Hasil dari bagian pendapatan tenaga kerja langsung untuk gula adalah sebesar $15,63 \%$. Balas jasa untuk sumbangan input lain diperoleh dari perbandingan sumbangan input lain dengan margin dikali dengan $100 \%$. Hasil dari balas jasa untuk input lain gula adalah sebesar $25,25 \%$. Keuntungan perusahaan yang diperoleh dari nilai tambah tebu menjadi gula sebesar $59 \%$, nilai ini diperoleh dari perbandingan keuntungan dengan margin dikali dengan $100 \%$.

\section{KESIMPULAN}

Dari hasil penelitian dan pembahasan yang diuraikan sebelumnya, maka dapat diambil beberapa kesimpulan tersebut:

1. Persen pertumbuhan produksi serta produktvitas tebu dan gula dari tahun 2007-2017 selalu berfluktuasi. Naik turunnya produksi tebu dan gula setiap tahun banyak faktor yang mempengaruhi seperti jumlah produksi, konversi lahan, dan kadar rendemen gula dalam tebu.

2. Analisis nilai tambah tebu dengan menggunakan metode hayami mendapatkan hasil bahwa rasio nilai tambah menjadi gula adalah positif karena rasio nilai tambah gula $>0 \%$ yaitu sebesar $75 \%$.

\section{DAFTAR PUSTAKA}

1. Sutardjo. 1996. Budidaya Tanaman Tebu. Bumi Aksara. Jakarta.

2. Purwono, 2003. Penentuan rendemen gula tebu secara cepat. Paper Individu m.k. Pengantar Falsafah Sain, Institut Pertanian Bogor.

3. Sofyan Assauri,. 1998. Manajemen Produksi dan Operasi. Penerbit FE-UI. Jakarta

4. Sirait, Lilis. 2009. Beberapa Faktor Sosial Ekonomi Yang Mempengaruhi Kesempatan Kerja, Produktivitas, Dan Pendapatan Petani Sayur Mayur Di Kabupaten Karo.

5. Dinas Perkebunan Provinsi Sumatera Utara. 2008. Teknologi Peningkatan Produktivitas Tebu Rakyat dan Pengenalan Varietas Unggul diSumatera Utara. Medan. 
6. Baroh, I. 2007. Analisis Nilai Tambah dan Distribusi Keripik Nangka Studi Kasus pada Agroindustri Keripik Nangka di Lumajang. LP UMM. Malang.

7. Suryana, A. 1990. Diversifikasi Pertanian dalam Proses Mempercepat Laju Pembangunan Nasional. Pustaka Sinar Harapan, Jakarta.

8. Hardjanto, W. 1993. Bahan Kuliah Manajemen Agribisnis. Jurusan Ilmu-ilmu Sosial Ekonomi Pertanian. Fakultas Pertanian. IPB. Bogor

9. Sugiyono. 2013. Metode Penelitian Pendidikan Pendekatan Kuantitatif, Kualitatif, dan R\&D. Bandung: Alfabeta.

10. Suprapto, 2006. Proses Pengolahan dan Nilai Tambah.Penebar Swadaya, Jakarta.

11. Hayami, et all. 1987. Agricultural Marketing and Processing in Upland Java : A Prospectif from a Sunda Village, Bogor. 